\title{
ANALISA PENAMBAHAN BERAT SIMULATOR TERHADAP STABILITAS KAPAL LATIH BUNG TOMO
}

\author{
Rudy Sugiharto ${ }^{a}$ dan Daviq Wiratno ${ }^{b}$ \\ Politeknik Pelayaran Surabaya
}

\begin{abstract}
ABSTRAK
Tujuan dari penelitian ini adalah untuk menganalisa penambahan simulator pada KL. Bung Tomo terhadap stabilitas kapal dan juga keselamatan kapal. Metode penelitian yang dilakukan yaitu metode proaktif dimana metode tersebut merupakan analisa yang dilakukan sebelum hal tersebut dilaksanakan.Setelah melakukan pengumpulan data kemudian menganalisa diperoleh Penambahan simulator pada KL Bung Tomo seberat 2 ton yang diletakkan pada belakang wheel house akan menghasilkan nilai $L C G=25,95$ dan $K G=$ 3,697.Yang artinya, penambahan simulator tersebut masih dapat dilakukan dan kapal masih dalam kondisi aman dilihat dari segi stabilitas dan IMO regulation.
\end{abstract}

\section{Kata kunci : stabilitas, simulator, keselamatan, deskriptif}

\section{PENDAHULUAN}

Pada awal tahun 2018 ini Politeknik Pelayaran Surabaya mempunyai kapal latih sendiri yang cukup mumpuni dalam rangka laboratorium maupun workshop riil berjalan untuk meningkatkan kompetensi bagi para tarunanya. Kapal yang diberi nama KL. Bung Tomo dengan panjang keseluruhan (Length Over All) 63 meter, lebar (Breadht Moulded) 12 meter, kecepatan 12 knot, tenaga mesin 2 X 1000 HP, dimana mampu menampung 100 orang taruna dalam setiap pelayarannya.

Dalam desainnya, KL Bung tomo mempunyai 2 buah anjungan, dimana pada bagian depan terdapat anjungan sebenarnya yang digunakan untuk para perwira kapal membawa kapal dan di belakangnya terdapat anjungan latihan sebagai tempat para taruna berlatih membawa kapal. Pada saat ini anjungan latihan belum dilengkapi peralatan simulator yang dapat dipakai para taruna untuk belajar membawa kapal.

Dalam waktu yang akan datang dimungkinkan adanya penambahan peralatan simulator pada anjungan latihan yang mana akan berimbas pada adanya penambahan berat pada kapal. Dengan adanya penambahan berat maka terdapat perubahan stabilitas kapal.

Stabilitas adalah keseimbangan dari kapal, merupakan sifat atau kecenderungan dari sebuah kapal untuk kembali kepada kedudukan semula setelah mendapat senget (kemiringan) yang disebabkan oleh gayagaya dari luar (Rubianto, 1996). Stabilitas statis adalah stabilitas kapal pada saat diam yang terdiri dari stabilitas melintang, tegak, membujur. Untuk mempelajari stabilitas maka harus memahami titik-titik penting pada stabilitas. Stabilitas statis diperuntukkan bagi kapal dalam keadaan diam dan terdiri dari stabilitas melintang dan membujur. Stabilitas melintang adalah kemampuan kapal untuk tegak sewaktu mengalami senget dalam arah melintang yang disebabkan oleh adanya pengaruh luar, stabilitas membujur adalah kemampuan kapal untuk kembali ke kedudukan semula setelah mengalami senget dalam arah yang membujur.

Letak titik berat kapal sangat tergantung pada penempatan bobot-bobot di atas kapal. Pada kapal kosong letak titik berat sudah dapat diketahui dari percobaan stabilitas namun dengan adanya pemuatan, pembongkaran, pergeseran muatan, pemakaian bahan bakar, pemakaian air 
tawar dan kegiatan lain di atas kapal maka letak titik berat kapal akan berubah kedudukannya sehingga kita perlu mengetahui dengan pasti letak titik berat kapal selesai kegiatan. Kapal juga dapat diibaratkan sebagai timbangan secara tegak dengan titik tumpunya adalah titik berat kapal. Perhatikan percobaan di bawah ini:

Apabila sebuah balok yang homogen dengan berat $\mathrm{W}$ maka letak titik beratnya (G) adalah pada setengah panjangnya, sehingga apabila diberi tuas pada titik beratnya maka akan dalam keadaan seimbang.

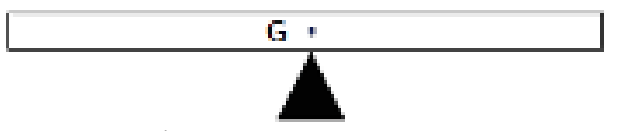

Gambar 1 : Perumpamaan Pergeseran Titik Berat Kapal

Tujuan dari penelitian ini adalah :

1. Mendapatkan data stabilitas KL. Bung Tomo setelah adanya penambahan simulator;

2. Mendapatkan data stabilitas penambahan simulator pada KL. Bung Tomo terhadap keselamatan kapal.

\section{METODE PENELITIAN}

Jenis penelitian yang digunakan dalam penelitian ini adalah penelitian deskriptif, yang menggambarkan sejumlah data yang kemudian dianalisis dan dibandingkan berdasarkan kenyataan yang sedang berlangsung selanjutnya mencoba untuk memberikan pemecahan masalah yang ada supaya memperoleh hasil yang lebih baik dari sebelumnya. Penelitian ini memusatkan perhatian pada analisa penambahan simulator pada KL. Bung Tomo yang akan mempengaruhi perubahan stabilitas kapal. Metode pendekatan penelitian yang dapat dilakukan yaitu metode proaktif dimana metode tersebut merupakan analisa yang dilakukan sebelum tersebut dilaksanakan.Hal ini dapat dilaksanakan dengan membandingkan perencanaan penambahan simulator yang sudah diadakan dari lembaga lain yang mempunyai kapal latih sejenis.

Subjek Penelitian berfokus pada analisa penambahan simulator pada kapal latih Bung Tomo yang berakibat adanya penambahan bobot sehingga merubah stabilitas kapal. Sedangkan lokasi penelitian pada satu tempat (objek) yaitu Kapal Latih Bung Tomo yang dioperasikan oleh Politeknik Pelayaran Surabaya.

Tahapan-tahapan yang dilakukan dalam penelitian ini meliputi survei pendahuluan, studi literatur, identifikasi masalah, perumusan masalah,penetuan tujuan penelitian, pengumpulan dan pengolahan data, analisa data, rekomendasi perbaikan, kesimpulan. Pada tahap survei pendahuluan dilakukan survei untuk mendapatkan gambaran dari kondisi sebenarnya obyek yang diteliti yaitu data stabilitas awal pada KL. Bung Tomo sebelum ditambahkan simulator serta mencari data dari lembaga lain yang dalam proses penambahan simulator di atas kapal latih yang sejenis. Tahap studi literatur yaitu mempelajari teori dan ilmu pengetahuan yang relevan dengan permasalahan yang diteliti. Sumber literatur diperoleh dari buku cetak, jurnal ilmiah, maupun sumber tulisan lainnya. Pada tahap identifikasi masalah dilakukan untuk mencari kekurangan-kekurangan yang ada dalam proses analisa perubahan stabilitas pada kapal latih Bung Tomo. Untuk tahap perumusan masalah mengenai hal-hal yang dapat menghambat proses analisa. Tahap penentuan tujuan Penelitian diperlukan untuk dapat merencanakan langkah yang dapat diambil pada penelitian sehingga penelitian dapat lebih terfokus dan dapat dijalankan dengan lancar. Tahap terakhir yaitu pengumpulan dan pengolahan data yang, meliputi identifikasi peralatanperalatan yang direncanakan untuk dipasang pada anjungan latih KL. Bung Tomo dengan spek dan analisa berat, Memetakan identifikasi yang ada dalam data awal dan peralatan yang dipasang sehingga dapat dianalisa perubahan stabilitas yang akan ada, Selanjutnya tahap Analisis dan Pembahasan, yaitu 
menganalisa penambahan bobot dari dipasangnya peralatan simulator baru di anjungan latih sehingga merubah stabilitas awal dari KL. Bung Tomo. Tahap Rekomendasi Perbaikan, dilakukan analisis mengenai perancangan perbaikan yang dapat diterapkan pada perencanaan pengadaan simulator di KL. Bung Tomo. Dan yang terakhir adalah Kesimpulan.Pada tahap ini ditarik beberapa kesimpulan sebagai jawaban dari permasalahan yang diangkat dalam penelitian. Berdasarkan hasil pengambilan kesimpulan maka dapat diberikan beberapa saran ataupun usulanusulan perbaikan dalam upaya meningkatkan kinerja dan produktifitas instansi dan untuk melakukan penelitian lebih lanjut.
Di dalam pelaksanaan penelitian ini, kami menggunakan data penambahan simulasi yang telah dilaksanakan pada kapal latih Malahayati miklik BP2IP Aceh. Dimana pekerjaan penambahan simulator telah selesai dilaksanakan pada awal tahun anggran 2018. Berikut ini merupakan data nama-nama peralatan simulator Full Mission Ship Maneuvering Simulator $180^{\circ}$ yang telah dipasang:

Berikut merupakan pengecekan stabilitas pada kondisi 2 dengan kondisi Departure, 100\% Cadet \& Passengers, 100\% Cargo. Diketahui bahwa nilai KN pada booklet sesuai dengan perhitungan di bawah ini.

\begin{tabular}{|c|c|c|c|c|c|}
\hline $\begin{array}{l}\text { wan } \\
\text { wed } \\
\text { ipt: } \\
\text { है }\end{array}$ & $\begin{array}{l}69,00 \\
54.86 \\
12.00 \\
100\end{array}$ & $\begin{array}{l}\text { Kondes? } \\
n \\
n \\
n\end{array}$ & & & \\
\hline & A-cosives & is. & cetio & o & $t$ \\
\hline imens & * & $\begin{array}{c}\text { Tobsi } \\
\text { cakscm. }\end{array}$ & wasiven & seasteres & whest an? \\
\hline Lont sals & 100 & & & & 892,419 \\
\hline Gem 8 Lagojes & not & 1000 & & $\operatorname{son} 20$ & 0.100 \\
\hline Povialon 200 & 100 & $20 x$ & & 200 & 3,000 \\
\hline Bohun Bsore & 100 & 2000 & & $200 \mathrm{r}$ & 4,000 \\
\hline Toeal & 13si & and & & sand & rive \\
\hline Finder o Lutpoge: & 22.50 & 0000 & & 2502 & 8,100 \\
\hline Wos Luppeger & 400 & $a 000$ & & 1000 & $\$, 100$ \\
\hline Gadet thore a cuepapes & $n=0$ & aan & & $\operatorname{son}$ & 0,100 \\
\hline 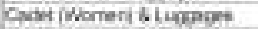 & 22,20 & $20 x$ & & 2002 & 0,100 \\
\hline Pasaryom On Aata Hoom & 10000 & $a 000$ & & $20000^{\circ}$ & 0,100 \\
\hline Carpo as Cargo Hedd & $1 \infty$ & asool & & 20000 & 60.600 \\
\hline tatar & nise & and & & Aal & wos \\
\hline FPTE & ins & $30 \mathrm{x}$ & 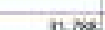 & 1007 & 30 \\
\hline Fotwatiph & $\sin$ & zax & sent & stax & 13,650 \\
\hline 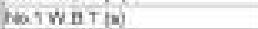 & 300 & 2000 & sxuses & sea & 12,850 \\
\hline DQZWWATIM & $3 m$ & 2000 & 20.000 & 280 & 29,710 \\
\hline Hด2WRT IS & $\sin$ & sox. & $x a x$ & sest & 28,710 \\
\hline 10ขसWT: & $\operatorname{sen}$ & aod & wopes & $\cos \frac{1}{1}$ & $45,46 \mathrm{~J}$ \\
\hline feas IfWT: & 100 & 1000 & wows & 2000 & 48,669 \\
\hline $402 F W 789$ & $\operatorname{san}$ & $\operatorname{son} x$ & soen. & 29000 & 35,460 \\
\hline morw? & $\operatorname{sen}$ & 2000 & xis & $20 x$ & 38,462 \\
\hline 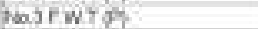 & sans & 1000 & xalae & 1000 & 35,100 \\
\hline $\sin 3 F w \tau ;$ & 390 & 3000 & shese & 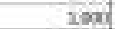 & 36,100 \\
\hline WaSFOTFI & 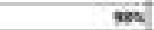 & $300=$ & $x_{102}$ & exsed & 20,785 \\
\hline Doirotial & m & 2000 & 2a, ie & जक्ये & 36,760 \\
\hline $62+079$ & $3 n$ & 1000 & 3xw1. & 400 & 36,713 \\
\hline $102 F 07(6)$ & 250 & ज्ञ⿰冫中⿰㇀丶㇀ & nis & ensol & $32,7+2$ \\
\hline $\ln 3 F 0 T A$ & +2 & 200 & $24 \mathrm{mi}$ & $2 \mathrm{~m}$ & 21,055 \\
\hline nespot ofi & 36 & 2000 & 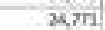 & 1000 & 21,062 \\
\hline FODT 9 & 90 & $\operatorname{son}$ & 4,100 & and & 3.491 \\
\hline FODT(S) & $\infty$ & aबan & ลें & sहs: & 2,49 \\
\hline उEWAGE TK $T$ (C) & a & करण & $2, \pi$ & Ims & $3,0 \mathrm{ri}$ \\
\hline DLGE TANK \& & an & 2000. & $5 \sin$ & करती & 5,028 \\
\hline SUOOE TRNK \S1 & a & 3000 & 557 & A.45 & 5,000 \\
\hline coter & 1684 & $a \alpha^{\prime \prime}$ & $\sec \pi$ & 20न7 & sue \\
\hline tark & & & & & $2 \operatorname{coses}$ \\
\hline
\end{tabular}


Analisa Penambahan Berat Simulator Terhadap Stabilitas Kapal Latih Bung Tomo Rudy Sugiharto ${ }^{a}$ dan Daviq Wiratno ${ }^{b}$

\begin{tabular}{|c|c|c|}
\hline & \multirow[b]{2}{*}{ I } & \multirow{3}{*}{$\frac{K}{1 T^{*}} \mathrm{SG}$} \\
\hline & & \\
\hline MEMS & FSM (x,m)m & \\
\hline Light ship & 0.000 & \\
\hline Crew \& Luggages & 0,000 & \\
\hline Provision Store & 0,000 & \\
\hline Bosun Store & 0,000 & \\
\hline Total & 0,000 & \\
\hline Irisstruntar \& Livgugeges: & 0,000 & 0,000 \\
\hline VIP \& L Logages & 0.000 & 0.000 \\
\hline Cacat (Men) \& Luggoges & 0,000 & 0,000 \\
\hline Caclet (Wormen) a Lupgages & 0.000 & 0,000 \\
\hline Passengers On Aula Room & 0.000 & 0,000 \\
\hline Cargo on Cargo Hold & 0,000 & 0,000 \\
\hline total & 0,00 & 0,00 \\
\hline$F, P, T(C)$ & 0.000 & 0.000 \\
\hline NO 1 VUET $P$ P & 12,305 & 32.617 \\
\hline No. 1 W.B.T (6) & 12.305 & 12.613 \\
\hline $\mathrm{Na} 2 \mathrm{WBT}(\mathrm{P})$ & 0,000 & 0,000 \\
\hline NOZZNB.T (S) & 0.000 & 25,225 \\
\hline No. T F.W.T $(P)$ & 0,000 & 0,000 \\
\hline No 1 FWT (S) & 0,000 & 0,000 \\
\hline No.2F.W.T (P) & 0.000 & 0,000 \\
\hline No 2 F.W.T (S) & 0,000 & 0,000 \\
\hline No.3F W.T (P) & 0.000 & 0,000 \\
\hline No.3F.W.T (B) & 0,000 & 0,000 \\
\hline $\mathrm{No}, 1 \mathrm{~F}, \mathrm{~T}, \mathrm{~T}(\mathrm{P})$ & 0.000 & 0,000 \\
\hline No.1 F.O.T (8) & 0,000 & 0,000 \\
\hline Na.2FOT (P) & 0,000 & 0,000 \\
\hline No.ZF.Q.T (S) & 0.000 & 0.000 \\
\hline Na.3F.O.T (P) & 0,000 & 0,000 \\
\hline No $3 F, 0 . T$ (5) & 0.000 & 0,000 \\
\hline F.D.D.T (P) & 0,000 & 0,000 \\
\hline FODT (E) & 0,000 & 0,000 \\
\hline SEWAGE TK (O) & 0.000 & 0.000 \\
\hline BILGE TANK (P) & 0,000 & 0,000 \\
\hline SLUDGE TANK (S) & 0,000 & 0,000 \\
\hline total & 24.61 & 50.45 \\
\hline TOTAL & & 50,45 \\
\hline
\end{tabular}

\begin{tabular}{|c|c|c|c|c|c|}
\hline & & t & eat & H. & AFH. \\
\hline mans & Fassi Whaght & Its ind & Moneres itial & $\operatorname{escon} x$ & Menestites \\
\hline Lont saip & $899,6+9$ & 25,362 & 2120034 & 4.8601 & $43 \sin 35$ \\
\hline Crew 5 Legpopen & 2,160 & 56.220 & 3e:16 & 7,460 & 15ees: \\
\hline Pewhow stien & 3,000 & 5,000 & 18.00 & 5,150 & is,as: \\
\hline Eounn Siors & 4,000 & 58,200 & 20286 & $5,3 / 2$ & Dis \\
\hline Total & 2100 & mine & Itson: & xeint & 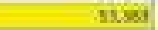 \\
\hline 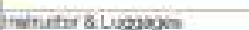 & 1,000 & $985:$ & 19 & 7.460 & tos \\
\hline WPS Liogens & 9,400 & 14,000 & 19 & 7,400 & 2.50 \\
\hline 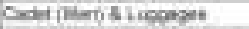 & $a, 000$ & 32,400 & $8+60$ & 2,000 & iset \\
\hline Cest iWurert s Lughopm & 2,060 & 31,283 & e.5? & 4.665 & 200 \\
\hline Passergers On Auds Acosen & 50,600 & $\$ 5, a c 0$ & $=0 \times$ in: & 4,650 & 205 \\
\hline Carpo an Carge Hodd & 60,000 & 48,410 & 20000 & 4,215 & 245.5 \\
\hline totes & nua & leass: & 32346 & si, 10 & xoL: \\
\hline FPTIP & 0900 & 50.545 & $\pi m$ & $0 \mathrm{~cm}$ & \\
\hline WhIWATIP. & 5.918 & 47,712 & 20 & $0<4$ & $2 n$ \\
\hline TotwBYis & 6,618 & 47,712 & senes. & $0,49 ?$ & 305 \\
\hline 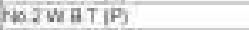 & 20,710 & $-1,754$ & 763 & $3, \pi \mathrm{ra}$ & nite \\
\hline 602 WATI5 & 20.710 & $-1,754$ & -1613 & 3,779 & $\pi, \sqrt{4}$ \\
\hline HoIFWTP & 43,689 & 39.719 & $160 \mathrm{~kg}$ & 0.689 & anm \\
\hline DAFT is? & 40,480 & 3,712 & 1616.29 & 0,658 & $x, r y$ \\
\hline $162+w Y ?$ & 35,469 & 33,272 & 1.10000 & $0,62+$ & $n=0$ \\
\hline FลFWT & $25,4 \in$ & $73,2 \pi$ & 11200 & 0,01 & $2 \pi$ \\
\hline bostwtos & 39,1600 & 27,500 & 100642 & 0.516 & nas: \\
\hline No. 3 FWT iss & 36,160 & 27.900 & 100442 & 0.616 & $n x$ \\
\hline Dotrath & 30,140 & 21,200 & $\cos 0 \mathrm{~s}$ & 0,000 & inn \\
\hline Hatratel & 35,140 & 23800 & 600.06 & 0.605 & is \\
\hline 202Fotg & 20,400 & 18.era & $\operatorname{sen} 2$ & 0.724 & $\pi, 19$ \\
\hline lazrorga & 30,260 & 16,064 & $\cos 12$ & 0,724 & 2.78 \\
\hline no3fotg & 20,634 & 2.737 & $\operatorname{sen}$ & 2.209 & $\alpha \pi$ \\
\hline hatargi & 20,594 & 2,737 & 56.67 & 3,2003 & 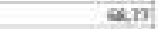 \\
\hline roating & 3,420 & 15,600 & 1917 & 2,705 & 2025 \\
\hline Fontigt & 3,421 & 15,000 & (23). & $2.70 \mathrm{a}$ & ais \\
\hline SEWAó TK (C) & 0,060 & 4,060 & 100. & $2,60 \mathrm{a}$ & $\omega$, \\
\hline DLOE TANK OP? & 9,800 & 93.448 & $e m$ & $Q 000$ & ore \\
\hline SUDOE TANK (S) & 0,000 & 72,540 & 2500 & 0,000 & ane \\
\hline tete & 4e.sa & mase: & 10.74323 & as.se & $\sec 55$ \\
\hline$=$ & atist & isss: & romess & 24. & \\
\hline
\end{tabular}


Jurnal Dinamika Bahari

Vol. 9 No. 2 Edisi Mei 2019

\begin{tabular}{|c|c|c|c|c|c|}
\hline dratt & displt & Wond & midf & mic & tpC \\
\hline 2,858 & 1425,000 & 26,371 & 24,948 & 23,46 & 6,22 \\
\hline 2,863 & 1429,000 & 26,364 & 24,930 & 23,55 & 6,23 \\
\hline 2,863 & 1428,636 & 26,365 & 24,932 & 23,549 & 6,231 \\
\hline
\end{tabular}

\begin{tabular}{|c|c|c|c|}
\hline $\mathrm{kh}$ & $\mathrm{kmm}$ & $\mathrm{kmm}$ & wps \\
\hline $1,56 \mathrm{t} 2$ & 6,211 & 100,093 & 607,99 \\
\hline 1,567 & 6,204 & 100,074 & 608,87 \\
\hline 1,567 & 6,205 & 100,076 & 6008,785 \\
\hline
\end{tabular}

\begin{tabular}{|c|c|c|c|}
\hline mida & wsa & c & फ \\
\hline 0 & 814,31 & 0,652 & 0,665 \\
\hline 0 & 816,19 & 0,653 & 01,667 \\
\hline 0,000 & 816,015 & 0,553 & 0,657 \\
\hline
\end{tabular}

\begin{tabular}{|c|c|}
\hline sw & on \\
\hline 0,814 & 0,979 \\
\hline 0,815 & 0,979 \\
\hline 0,815 & 0,979 \\
\hline
\end{tabular}

\begin{tabular}{|c|c|}
\hline Disghacement- & 1.A28.64 Oan Tabe Tack \\
\hline Equhalent Draft= & 2863 tharthterenlas \\
\hline Forewart: = & 1,4330 alt dat-Trim \\
\hline Aft $=$ & 19,6267 Couir Drah- (Trim'LorisPP) \\
\hline Mean= & 10,53 Gift dact fir daity/2. \\
\hline Trim= & -18.194 EG"DiszJMTC"100) \\
\hline
\end{tabular}

\begin{tabular}{|c|c|}
\hline$t C G=$ & 25,95 Oam label lank \\
\hline $108=$ & 55,94 03ri huterpows strim berie \\
\hline$B G=$ & $-29,99$ L्जिएक \\
\hline ICF $=$ & 54,51. Oari haterpolas (arim turai) \\
\hline $\mathrm{MTC}=$ & 23,55 Ominterpolas Strim tarif. \\
\hline WD. & 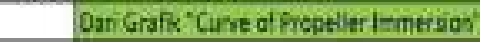 \\
\hline
\end{tabular}

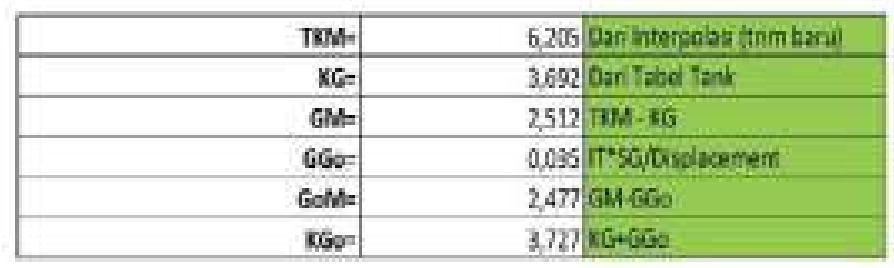



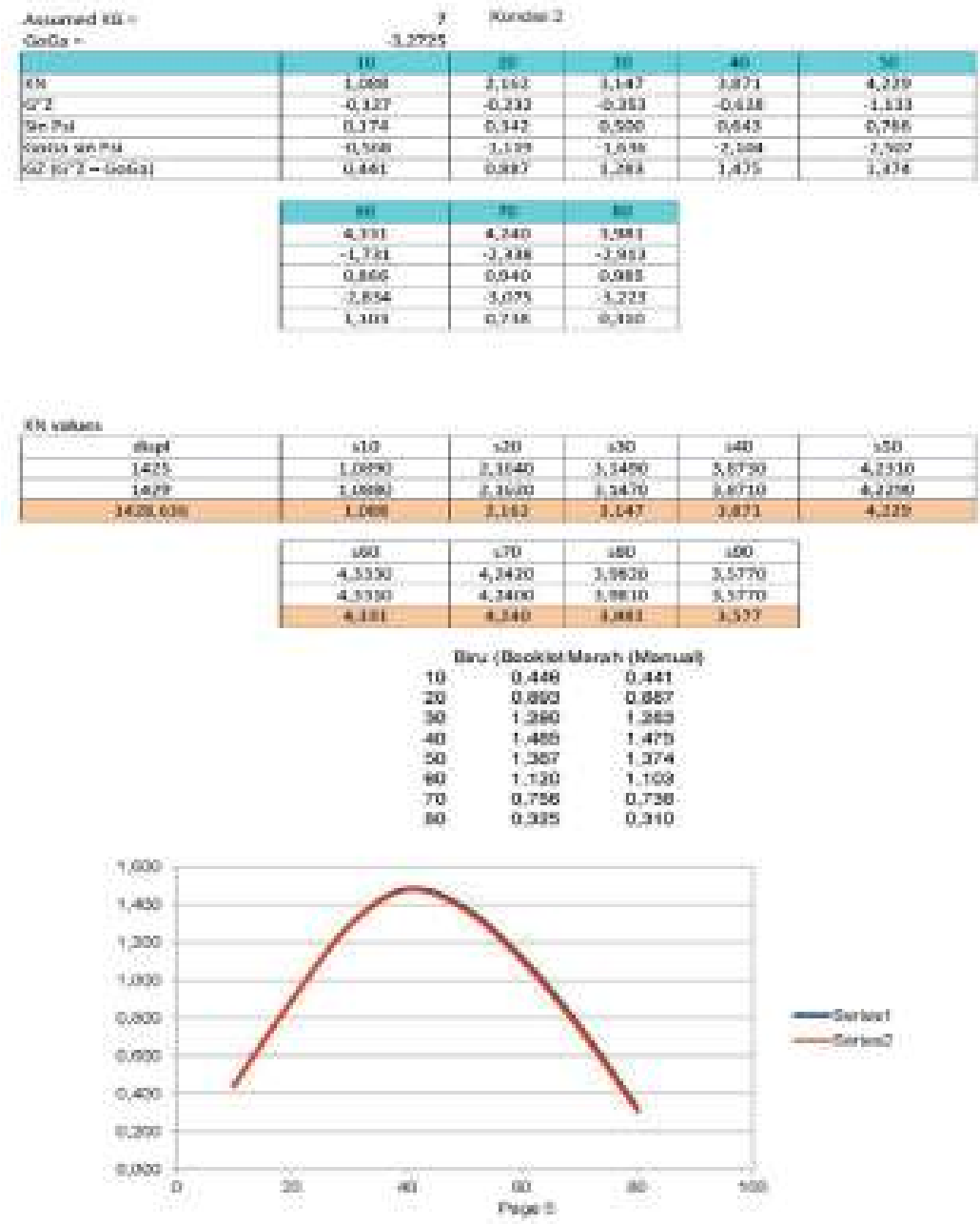

Dari grafik di atas diketahui bahwa perhitungan $\mathrm{KN}$ di booklet dengan perhitungan manual hampir sama.

Pada gambar 1 memperlihatkan kondisi ruangan simulator KL. Bung Tomo yang belum terpasang simulator. Dan pada gambar 2 memperlihatkan simulator Full Mission Ship Maneuvering Simulator $180^{\circ}$ yang telah terpasang pada sister ship KL. Bung Tomo yaitu KL. Malahayati.

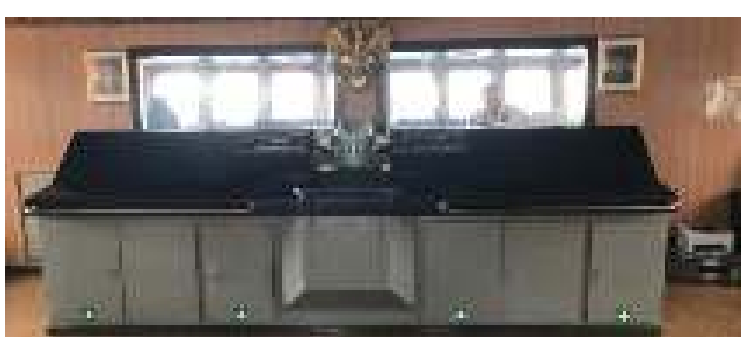

Gambar 1. Simulator (1)

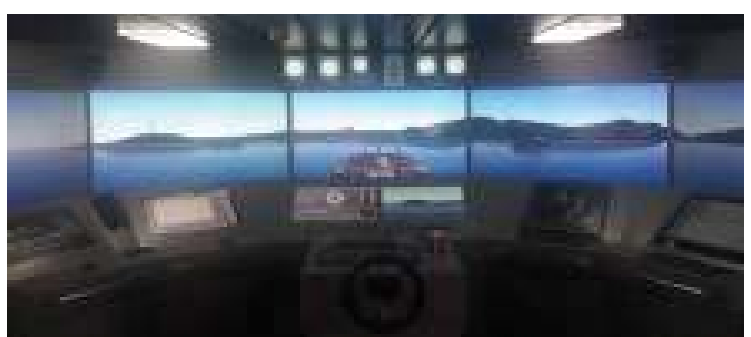

Gambar 2. Simulator (2)

Simulator ini didesain sebagai anjungan latih yang dilengkapi berbagai peralatan navigasi seperti Radar, AIS, ECDIS, GPS, Navtex, Steering, Telegraph dimana dapat dipergunakan berlatih pada saat praktek berlayar diatas KL. Bung Tomo.

Berikut merupakan kondisi kapal setelah dilakukan penambahan alat berupa simulator. 
Jurnal Dinamika Bahari

Vol. 9 No. 2 Edisi Mei 2019

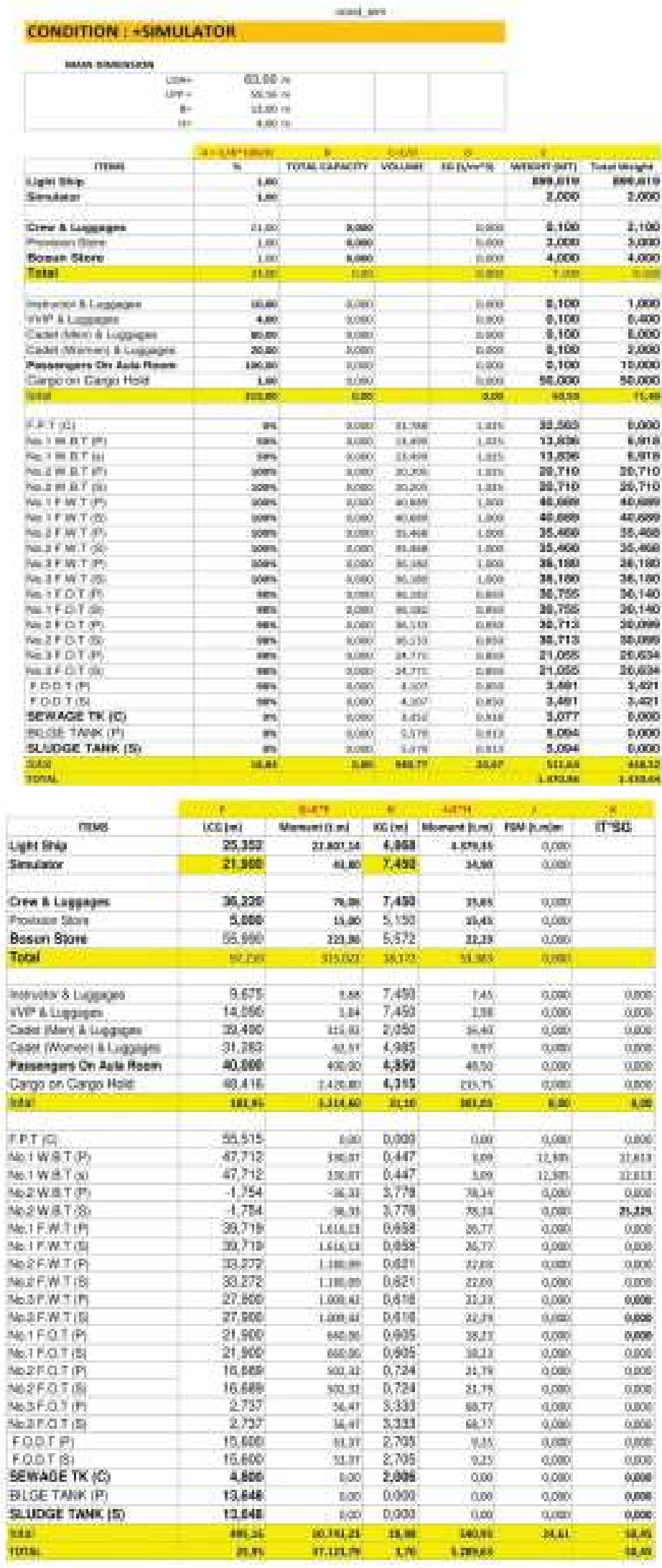

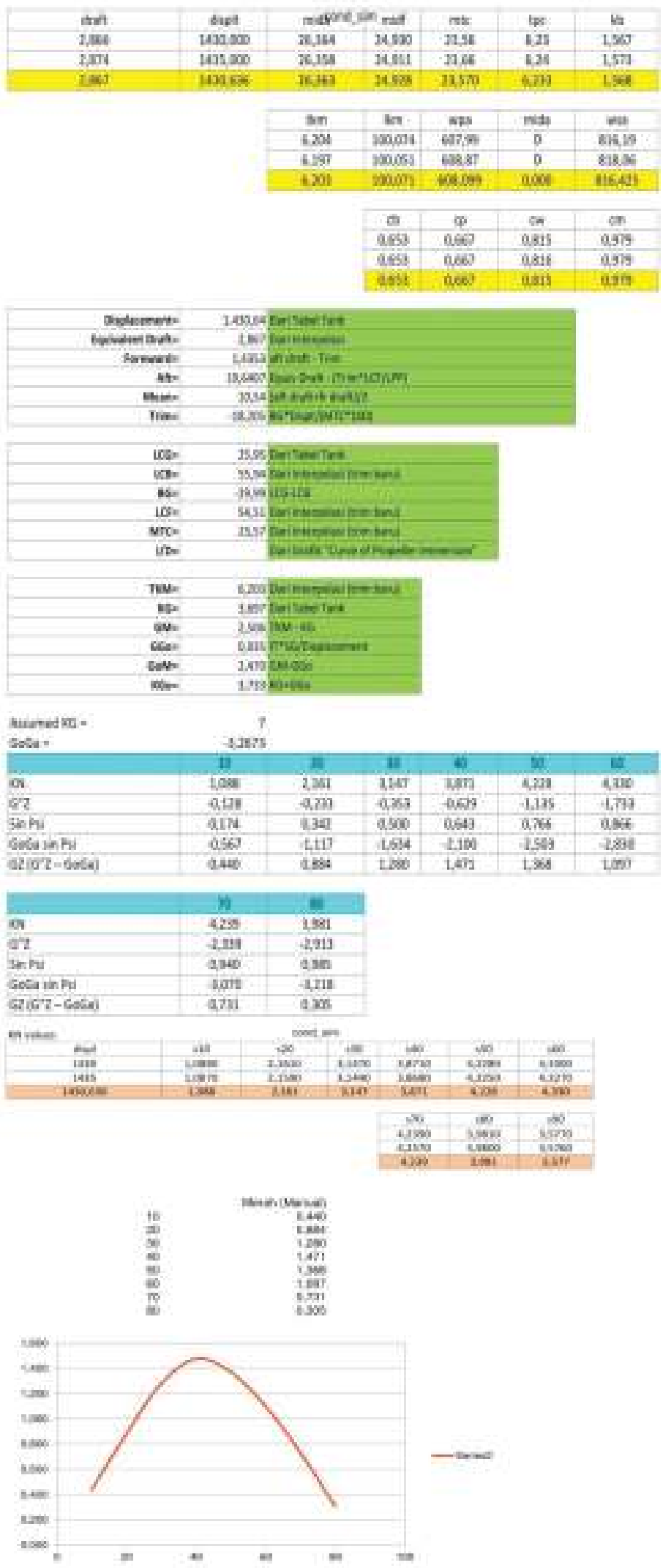

Untuk menentukan stabilitas Kapal Latih Bung Tomo telah memenuhi kriteria atau tidak maka dilakukan pengecekan perhitungan stabilitas menggunakan "Intact 
Stability Code, IMO” Regulasi A.749 (18), yang isinya adalah sebagai berikut:

Kriteria stabilitas untuk semua jenis kapal :

1. $\mathrm{e}_{0.30^{0}} \geq 0.055$ m.rad. Luas gambar di bawah kurva dengan lengan penegak GZ pada sudut $30^{\circ} \geq 0.055$ meter rad;

2. $\mathrm{e}_{0.40^{\circ}} \geq 0.09$ m.rad. Luas gambar di bawah kurva dengan lengan penegak GZ pada sudut $40^{\circ} \geq 0.09$ meter rad;

3. $\mathrm{e}_{30,40^{\circ}} \geq 0.03 \mathrm{~m} . \mathrm{rad}$. Luas gambar di bawah kurva dengan lengan penegak GZ pada sudut $30^{\circ} \sim 40^{\circ} \geq 0.03$ meter;

4. $\mathrm{h}_{30}{ }^{\circ} \geq 0.2 \mathrm{~m}$. Lengan penegak GZ paling sedikit 0.2 meter pada sudut oleng $30^{\circ}$ atau lebih;

$\mathrm{h}_{\max }$ pada $\phi_{\max } \geq 25^{\circ}$. Lengan penegak maksimum harus terletak pada sudut oleng lebih dari $25^{\circ}$;

5. $\mathrm{GM}_{0} \geq 0.15 \mathrm{~m}$. Tinggi Metasenter awal $\left(\mathrm{GM}_{0}\right)$ tidak boleh kurang dari 0.15 meter;

Batasan Stabilitas Menurut IMO Resolution A. 749 (18)
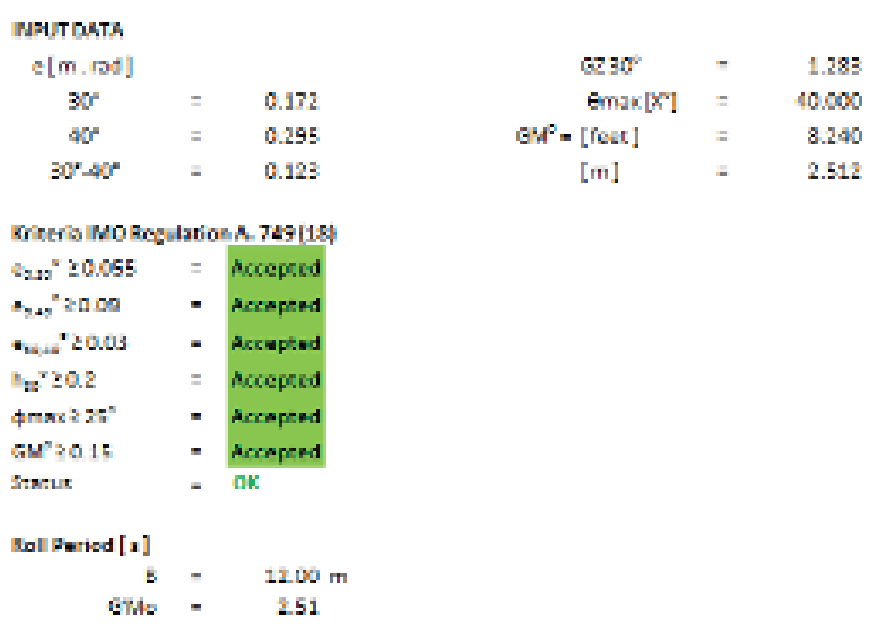

Period-0.798/ $/ 6 \mathrm{Mo}^{3} 1 / 2=\quad 6.0$

Gambar 3. Batasan Stabiitas pada Kondisi 2 (Tanpa Simulator)

Berdasarkan Gambar 3. stabilitas pada kondisi 2 (tanpa simulator) memenuhi kriteria IMO Regulation dengan roll period 6 detik.

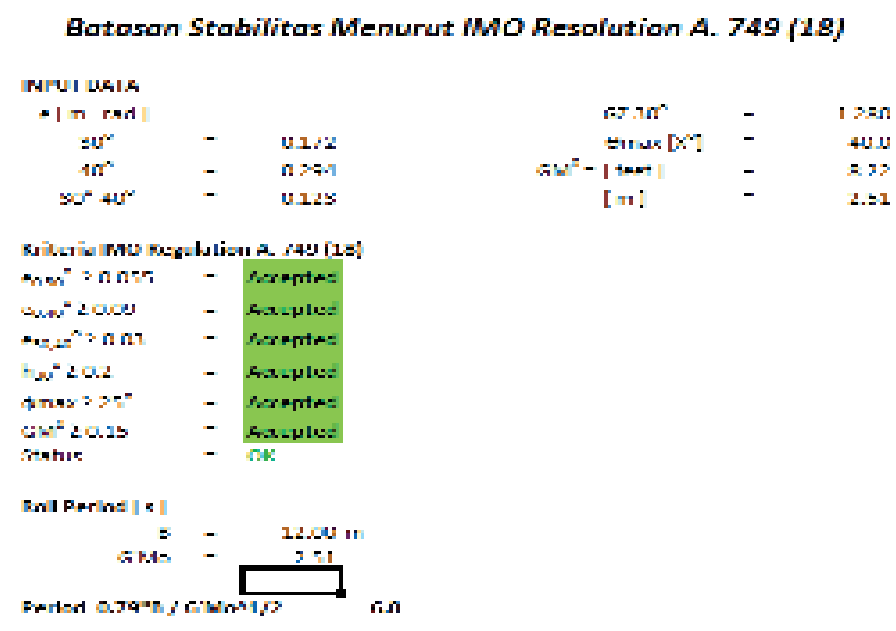

Gambar 4. Batasan Stabilitas (dengan Penambahan Alat Simulator)

Berdasarkan Gambar 4. Stabilitas pada kondisi dengan penambahan alat simulator memenuhi kriteria IMO Regulation dengan roll period 6 detik.

Dari hasil penelitian didapatkan dengan adanya penambahan berat berupa penambahan simulator di belakang anjungan masih dapat dilakukan dan kapal masih dalam kondisi aman dilihat dari segi stabilitas dan IMO regulation.

\section{DAFTAR PUSTAKA}

Istopo. 1972. Stabilitas Kapal untuk Perwira Kapal Niaga

Lewis, E. V. 1988. Principles of Naval Architecture Second Revision Volume I: Stability and Strength. New Jersey: The Society of Naval Architects and Marine Engineers 601 Pavonia Avenue Jersey City, NJ

Stokoe, E. 1975. Ship Construction for Marine Students. Principle Lecture in Naval Architecture at South Shields Marine and Technical College. Thomas Reed Publications Limited Sunderland and London

Wakidjo, P. 1972. Stabilitas Kapal Jilid II. Penuntun dalam Menyelesaikan Masalah 
Jurnal Dinamika Bahari Vol. 9 No. 2 Edisi Mei 2019

Young, \& Kemp. 1976. Ship Construction Sketches \& Notes. A Kandy Paperback Stokoe, E. A. 1975
Young, \& Kemp. 2001. Ship Stability Notes \& Examples Third Edition. Great Britain: Athenaeum Press Ltd, Gateshead, Tyne \& Wear 